発展する食品包装材

\title{
新規バリア材ポリグリコール酸フィルムの 香気バリア性に関する研究
}

\author{
増田 健一, 大場 弘行, 田中 幹雄
}

\begin{abstract}
プラスチック材料の香気バリア性に関する定量評価は, 香りやにおいに敏感な内容物の包装材料設計に とって非常に重要である。本論では，拡散セルとガスクロマトグラフ質量分析法 (Gas chromatography/ Mass spectrometry：GC/MS）を用い，動的ヘッドスペース法による香気バリア性の定量化を行った。 その 際，香気成分は分子量が大きく，透過速度が極めて小さいため，透過度の測定が困難であった。そこで，代 表的な香気成分であるリモネン，1-ブタノールおよび酪酸エチルと化学構造が類似しており，それらよりも 分子量の小さいシクロヘキサン，2-プロパノールおよび酢酸エチルを香気モデル物質として用いて，測定を 行った。ポリグリコール酸（PGA）のほか，ポリエチレンテレフタレート（PET), ナイロン MXD6 （NyMXD6）およびエチレン - ビニルアルコール共重合樹脂（EVOH）のフィルムについて測定した結果， PGA が 0\% RH および 100\% RH の両条件下で全ての香気モデル物質に対して最も良好なバリア性を示した.
\end{abstract}

\section{1. はじめに}

近年，市場では食品や飲料の香りに対する意識が高 まっており，香りをアピールポイントとした商品が多数 販売されている。代表的なものとして，お茶，コーヒー， 100\%果汁飲料などが挙げられる。 それに伴って食品包装 材料に対する「香気バリア性」の要求が高くなっている.

食品包装材料の香気バリア性評価方法は主に官能評価 で行われており, 定量的なデー夕はあまり見当たらな い、GC を用いた定量的な測定報告がいくつかあるが， ポリエチレン（PE）やポリプロピレン (PP)，ナイロン 6 (Ny6) といった比較的ローバリアの包装材料に関する 報告がほとんどである ${ }^{1) ~ 4)}$. 一般的にバリア性材料と呼

＊ポリグリコール酸 $(\mathrm{PGA})$

PGA は図-1のような構造式で示され, 生分解性を 有している. 非常に高価なため, 医療用縫合糸として実 用化されているにすぎなかったが，近年，当社が量産化 に成功し，包装材料にも応用可能な価格レベルになって きている. PGA は, その単純な構造から分子のパッキ ングが緻密であり, 既存ポリマーの中ではトップクラス の酸素および炭酸ガスバリア性を発揮する。 また，八イ バリア材料として広く普及しているNyMXD 6 や $\mathrm{EVOH}$ は，それぞれアミド基と水酸基が官能基として 働き, 主に水素結合によってバリア性が発現するが，水 分の影響でポリマー鎖の結合が弱まるため, 高湿度下で はバリア性が低下する。一方，PGA のガスバリア性は 水素結合によるものではなく, 高密度な構造に起因して いるため, 湿度の影響をほとんど受けない特徵がある.
ばれるPET，NyMXD6，EVOHについては，評価を 行っていても值が検出限界以下であり, 值が明確に報告 されている例は少ない，そこで本論では，香気バリア性 の定量評価法を確立し，該手法を用いてバリア性材料の 香気バリア性を明らかにすることとした，さらに，当社

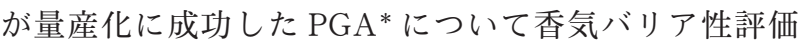
を行い，他バリア性材料との比較を行った。

\section{2. 気体透過の理論および評価法}

初めに，フィルムを気体が透過する際，どのような現 象が起こっているか説明する。図一2のようにフィルム を隔てて $2 つ の$ 空間があり, 左側が気体の圧力が高く, 右側が気体の圧力が低い場合, 気体は圧力の高い方から

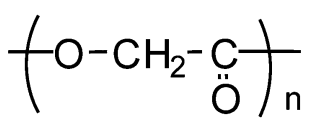

図-1 PGA の構造式

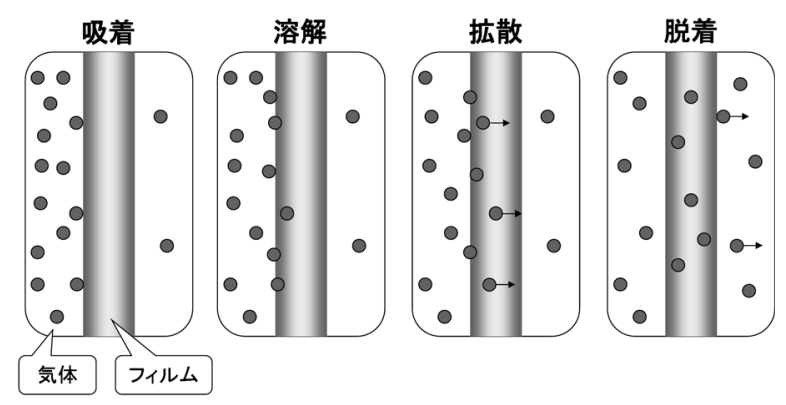

図-2 気体透過の模式図

増田 健一（ますだ けんいち）, 大場 弘行（おおば ひろゆき）, 田中 幹雄（たなか みきお）

(株)クレ八 加工技術センター 分析評価研究室 †311-3436 茨城県小美玉市上玉里 18-13 E-mail : k-masuda@kureha.co.jp 
低い方へ，つまり左側から右側へと流れる。ささらに気体 の透過を細かく観察すると, 以下のような過程で起こ る。 まず気体分子は压力が高い側のフィルム表面に凝 縮・吸着し, その後フィルム内へ溶解する. 溶解した気 体分子はフィルム内の濃度勾配が駆動力となり, 濃度の 低い方へ拡散する。拡散してフィルムの反対側へ到達し た気体分子はフィルム表面から脱着する。このような吸 着 $\rightarrow$ 溶解 $\rightarrow$ 拡散 $\rightarrow$ 脱着の過程により, 気体の透過が起こ る。この過程を式で表すと，

透過 : P (Permeation) =溶解 : S (Sorption) $\times$ 拡散 : D (Diffusion)

となり，フィルムのバリア性は気体に対する溶解や拡散 の難易によって決まる。気体はフィルムを構成している 分子鎖の隙間（フリーボリューム）を通り，透過してい る。フィルムの結晶部分は密な構造をしているため気体 は通ることが出来ない。このため, 気体の透過はフィル ムのアモルファス部分で起こっている，つまり，気体の 透過度はフィルムの結晶化度や添加剤の量によっても変 わるということである。

次に気体透過度を测定する手法を説明する ${ }^{5)}$ 。気体透 過度の評価法として, 差圧法と等圧法が挙げられる。差 圧法は，フィルムの片側に圧力をかけ，その反対側にお ける透過による圧力や容積の増加を測定する方法であ る。それに対して等圧法は大気圧下での测定であり， フィルム両側の測定気体の分圧差による透過をガス検知 器で測定する方法である。本論では試料にストレスがか からない等圧法を用いることにした。等圧法には測定の 手法として, 静的ヘッドスペース法と動的ヘッドスペー ス法がある。静的ヘッドスペース法は透過した気体を蓄 積していき，その透過した気体の濃度変化の傾きから気 体透過度を測定する評価手法である。それに対して動的 ヘッドスペース法は, 透過した気体濃度を連続的に測定 し，一定の透過量を示した時点を気体透過度とする評価 手法である。いずれの評価手法でも測定開始直後は透過 度が徐々に変化していく非定常状態であり，その後透過 度が安定した值を示す定常状態となる。通常, 透過度と
は定常状態時の值を指す。

評価手法の違いによるメリットとデメリットを表ー1 に示す。静的ヘッドスペース法は透過した気体を蓄積し ていけばよいため，装置を容易に組むことができる。ま た，わずかな変化でも透過の傾きを求めることができる ため, 微量測定が可能である. しかしながら, 傾きが求 まるまで測定を続ける必要があり, その都度測定を行っ ていかなければならないため，時間と労力がかかる。さ らに，密封系での測定であるため，分圧差の問題やリー ク・吸着による䛊差が生じやすい。このため，良好な再 現性を得ることが難しい. それに対して動的へッドス ペース法は，キャリアガスを流しながらの測定となるた め, 装置は複雑となってしまうが, 定常状態となった時 に数回測定するだけで再現性の良い結果を得ることがで きる，また，分圧差による問題やリーク・吸着による䛊 差が生じにくくなるが，ガスを流しているため測定気体 の濃度が低くなり, 微量分析が困難となる。本論では, これらのメリットとデメリットを理解し，適時適切な評 価手法を選定し, 評価した.

\section{3. 静的ヘッドスペース法による評価方法の検討}

初めに静的ヘッドスペース法について図ー3に示すよ うなセパラブルフラスコを用いて検討した。 セパラブル

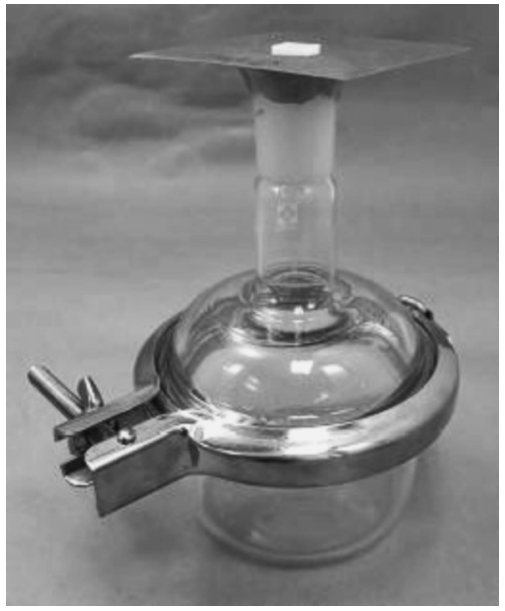

図－3 静的ヘッドスペース法概略図

表－1＼cjkstart評価手法の違いによるメリットとデメリット

\begin{tabular}{ccc}
\hline 評価手法 & メリット & デメリット \\
\hline & 微量測定が可能 & 測定時間が長い \\
静的ヘッドスペース法 & 測定機器が簡易 & 多数回の測定が必要 \\
& - & 再現性が悪い \\
\hline & 測定時間が短い & 微量測定は困難 \\
& 数回の测定で可能 & 測定機器が複雑 \\
& 再現性が良い & \\
& & -
\end{tabular}


フラスコ上部の口をアルミで封止した後, セパラブルフ ラスコ下層部にリモネン（柑橘様のにおいがする）を 10 $\mathrm{mL}$ 入れ, 測定対象のフィルムを挟んで, その上にセパラ ブルフラスコの上層部を取り付け, $30^{\circ} \mathrm{C}$ の条件下で保存 した. 2 週間後, セパラブルフラスコ上層部のアルミ部分 にシリンジを刺し込み，ヘッドスペースガスを抜き取り， GC/MS でセパラブルフラスコ上層部に透過してきたリ モネン濃度を測定した。透過したリモネン濃度からフィ ルムのリモネン透過度を算出した. 測定フィルムはPGA および PET で行った， 表-2 に示す通り，同一日の測定 バラツキは少なかったが, 別日に再度測定すると, 值が大 きくずれてしまった. セパラブルフラスコを用いた方法 では, 再現性の良い值を得ることが出来なかった．この原 因としてセパラブルフラスコを用いた香気バリア性評価 はリークや吸着の影響が大きいためであると考える。

\section{4. 動的ヘッドスペース法による評価方法の検討}

静的ヘッドスペース法はリークや吸着の影響を受け， 正確な香気成分透過度を測定することが困難であると考 え, 次に動的ヘッドスペース法を用いた香気成分透過試 験器を作製し, 再現性の良い香気成分透過度が測定でき る評価方法の構築を試みた。 作製した香気成分透過試験 器の概略図を図 -4 に示す. $30^{\circ} \mathrm{C}$ の恒温槽の中で, 測定 セルの下層に香気成分を $10 \mathrm{~mL}$ 入れ, 上層に Dry Air を $10 \mathrm{~mL} / \mathrm{min}$ で流し, 上層と下層の間にフィルムを挟 んだ。透過が定常状態になると下層から上層へ単位時間 あたり一定量の香気成分が透過するため, 上層には一定 濃度の香気成分が Dry Air とともに流れる. そのため, 上層から流れてくるDry Air の香気成分濃度を測定す ることにより，フィルムの香気成分透過度を求めること ができる，定常状態になるまで一定時間放置した後, 透
過した香気成分を含む Dry Air をガスタイトシリンジ で抜き取り，GC/MS で香気成分濃度を測定し，フィル ムの香気成分透過度を算出した。香気成分透過試験器は フィルムを透過した香気成分がガスによって速やかに測 定セル外へ運ばれるため, リークや吸着の影響を最小限 に抑えることができる.

香気成分としてリモネンを用いて PGA および PET で測定した結果，いずれも GC/MS の検出限界以下とな り，測定することが出来なかった。 リモネンは蒸気圧が 極めて低いため, Dry Air 側との分圧差も小さくなり, 測定可能なレベルの透過が起こらなかったことが原因で あると考えられる。そこで，リモネンよりも蒸気压が高 く, 香気成分に構造が類似している香気モデル物質を用 いて測定することとした。香気モデル物質には，バリア 性材料の透過特性が香気成分の構造別に評価できるよう に, 炭化水素類: シクロヘキサン, アルコール類 : 2-プ ロパノール, エステル類: 酢酸エチルの 3 つの構造別香 気モデル物質を用いた。

$0 \% \mathrm{RH}$ 条件での香気モデル物質透過度測定結果を表一 3 に示す. PGA および NyMXD6 は全ての香気モデル物 質で良好なバリア性を示した。 PET はシクロヘキサン

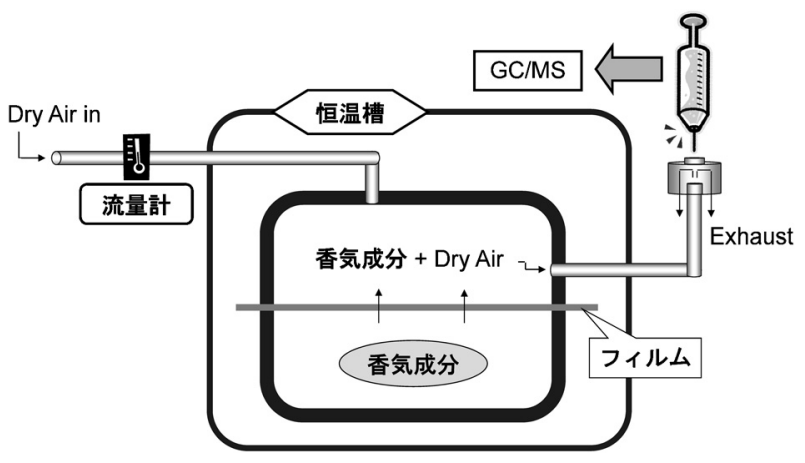

図-4 香気成分透過試験器概略図

表－2 静的ヘッドスペース法による香気バリア性評価結果

\begin{tabular}{c|c|c|c|c|c}
\hline \multirow{2}{*}{ フィルム } & \multicolumn{5}{|c}{$\begin{array}{c}\text { リモネン透過度@ } 30^{\circ} \mathrm{C} \\
\left(\mu \mathrm{g} \cdot 10 \mu \mathrm{m} / \mathrm{m}^{2} \cdot \mathrm{day} \cdot \mathrm{kPa}\right)\end{array}$} \\
\cline { 2 - 5 } & \multicolumn{3}{|c|}{ 同一日に評価 } & 別日に評価 & \multirow{2}{*}{ 標準偏差 } \\
\cline { 2 - 5 } & $\mathrm{n}-1$ & $\mathrm{n}-2$ & $\mathrm{n}-3$ & $\mathrm{n}-4$ & \\
\hline PGA & 7.0 & 7.0 & 5.3 & 27000 & 13497 \\
\hline PET & 9.2 & 7.7 & 7.7 & 360 & 176 \\
\hline
\end{tabular}

表一3 $30^{\circ} \mathrm{C} 0 \% \mathrm{RH}$ における香気モデル物質透過度

\begin{tabular}{|c|c|c|c|c|}
\hline \multirow{2}{*}{ 香気モデル物質 } & \multicolumn{4}{|c|}{$\begin{array}{c}\text { 香気モデル物質透過度@30 } 30^{\circ} \mathrm{C} 0 \% \mathrm{RH} \\
\left(\mu \mathrm{g} \cdot 10 \mu \mathrm{m} / \mathrm{m}^{2} \cdot \mathrm{day} \cdot \mathrm{kPa}\right)\end{array}$} \\
\hline & PGA & PET & NyMXD6 & EVOH \\
\hline シクロヘキサン & $<1.0$ & $1.5 \times 10^{2}$ & $<1.0$ & $1.6 \times 10$ \\
\hline 2-プロパノール & $<1.0$ & $<1.0$ & $<1.0$ & $8.3 \times 10^{5}$ \\
\hline 酢酸エチル & $<1.0$ & $1.2 \times 10^{5}$ & $<1.0$ & $1.9 \times 10^{3}$ \\
\hline
\end{tabular}


および酢酸エチルで大きな透過が確認された。 EVOH は2-プロパノールおよび酢酸エチルで大きな透過が確 認された.

\section{5. バリア性材料の香気成分透過挙動に関する考察}

前述のように蒸気圧が高い香気モデル物質を用いて動 的ヘッドスペース法による透過度測定を行うことにより， バリア性材料の香気バリア性を評価できることがわかっ た. 次に, 各バリア性材料における香気モデル物質の透過 挙動について考察する. 今日用いたバリア性材料および 香気モデル物質の構造は図ー5に示した通りである.

バリア性材料および香気モデル物質の官能基と香気モ デル物質透過度から, 表-4のような傾向が確認された。

表一4 から，PET およびNyMXD6 については，それ らと類似した官能基を有する香気モデル物質の透過が大 きいことが確認できる。これは，フィルムと香気モデル 物質の相溶性によるものであると考えられる. EVOH は同様の官能基を有する 2-プロパノールだけでなく, 酢
酸エチルの透過も確認された。これは，水酸基と似た構 造であるカルボニル基との相溶性によるものだと考えて いる. PGA については, 結合であるエステルと同じ構造 を持った酢酸エチルでも透過は見られなかった。これ は，相溶性よりも PGA の凝集エネルギーが大きいこと が影響し, 拡散が起こりにくくなったことによるものだ と考えられる.

次に, フィルムの両側に水で需らしたスポンジを入 れ，100\% RH 条件での香気モデル物質透過度を測定し た. 結果を表一5に示す. PGA は全ての香気モデル物質 に良好なバリア性を示した. PET は $0 \% \mathrm{RH}$ 条件での結 果より酢酸エチルで約 4 倍大きくなった. NyMXD6 お よび $\mathrm{EVOH}$ は $0 \% \mathrm{RH}$ 条件での結果と大きく異なり, NyMXD6 では 2-プロパノールおよび酢酸エチルの大き な透過が確認され, EVOH では全ての香気モデル物質 で大きな透過が確認された。

100\% RH 条件では 0\% RH 条件と結果が大きく異 なった。この原因として, 香気モデル物質の透過に水が

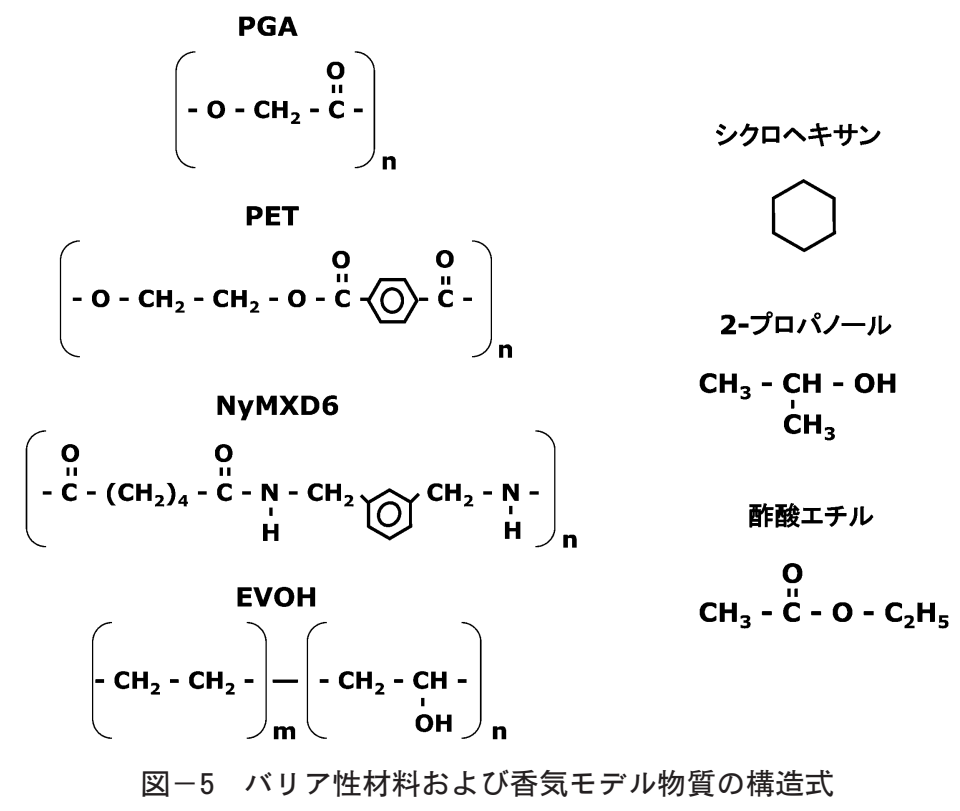

表 -4 バリア性材料および香気モデル物質の官能基と香気モデル物質透過度の関係

\begin{tabular}{|c|c|c|c|c|c|}
\hline \multirow[b]{2}{*}{ 香気モデル物質 } & \multirow[b]{2}{*}{ 官能基 } & \multicolumn{4}{|c|}{ バリア性材料の官能基 } \\
\hline & & $\begin{aligned} & \text { PGA } \\
-\mathrm{C}-\mathrm{O}- & - \\
\mathrm{O} & \end{aligned}$ & $\begin{array}{l}\text { PET } \\
-\mathrm{C}-\mathrm{O}- \\
{ }_{\mathrm{O}}\end{array}$ & $\begin{array}{c}\text { PET } \\
-\mathrm{N}-\mathrm{C}- \\
\mathrm{I}_{\mathrm{H}} \mathrm{I} \\
\mathrm{H}\end{array}$ & $\begin{array}{r}\mathrm{EVOH} \\
-\mathrm{C}-\mathrm{C}- \\
\mathrm{I} \\
\mathrm{OH}\end{array}$ \\
\hline シクロヘキサン & $-\mathrm{C}-\mathrm{C}-$ & $\bigcirc$ & $\bigcirc$ & $\bigcirc$ & $\bigcirc$ \\
\hline 2-プロパノール & $-\mathrm{OH}$ & $\bigcirc$ & $\bigcirc$ & $\bigcirc$ & $x$ \\
\hline 酢酸エチル & $\begin{array}{l}-\mathrm{C}-\mathrm{O}- \\
\mathrm{O}\end{array}$ & $\bigcirc$ & $\times$ & $\bigcirc$ & $\times$ \\
\hline
\end{tabular}




\section{表一5 $30^{\circ} \mathrm{C} 100 \% \mathrm{RH}$ における香気モデル物質透過度}

\begin{tabular}{|c|c|c|c|c|}
\hline \multirow{2}{*}{ 香気モデル物質 } & \multicolumn{4}{|c|}{$\begin{array}{c}\text { 香気モデル物質透過度@ } 30{ }^{\circ} \mathrm{C} 100 \% \mathrm{RH} \\
\left(\mu \mathrm{g} \cdot 10 \mu \mathrm{m} / \mathrm{m}^{2} \cdot \mathrm{day} \cdot \mathrm{kPa}\right)\end{array}$} \\
\hline & PGA & PET & NyMXD6 & $\mathrm{EVOH}$ \\
\hline シクロヘキサン & $<1.0$ & $<1.0$ & $9.0 \times 10$ & $3.1 \times 10^{3}$ \\
\hline 2-プロパノール & $<1.0$ & $<1.0$ & $1.8 \times 10^{7}$ & $3.0 \times 10^{7}$ \\
\hline 酢酸エチル & $<1.0$ & $4.7 \times 10^{5}$ & $9.4 \times 10^{5}$ & $1.6 \times 10^{6}$ \\
\hline
\end{tabular}

表 -6 フィルムの吸水率（水浸漬時）

\begin{tabular}{cc}
\hline フィルム & $\begin{array}{c}\text { 吸水率 }(\%) \\
\text { 水浸漬時 } / 20^{\circ} \mathrm{C}\end{array}$ \\
\hline PGA & 1.0 \\
PET & 0.4 \\
NyMXD6 & 5.8 \\
EVOH & 10.9 \\
\hline
\end{tabular}

表 -7 香気モデル物質の水への溶解度

\begin{tabular}{cc}
\hline 香気モデル物質 & 水への溶解度 $(\mathrm{g} / 100 \mathrm{~g})$ \\
\hline シクロヘキサン & $20^{\circ} \mathrm{C}$ \\
2 -プロパノール & 0.00079 \\
酢酸エチル & 100 \\
\hline
\end{tabular}

表 -8 計算による透過度と実測值

\begin{tabular}{|c|c|c|c|c|c|}
\hline \multicolumn{2}{|c|}{ 香気モデル物質 } & \multicolumn{4}{|c|}{$\begin{array}{c}\text { 香気モデル物質透過度@30 } 30^{\circ} \mathrm{C} 100 \% \mathrm{RH} \\
\left(\mu \mathrm{g} \cdot 10 \mu \mathrm{m} / \mathrm{m}^{2} \cdot \mathrm{day} \cdot \mathrm{kPa}\right)\end{array}$} \\
\hline & & PGA & PET & $\mathrm{EVOH}$ & $\mathrm{EVOH}$ \\
\hline \multirow{2}{*}{ シクロヘキサン } & 実測值 & $<1.0$ & $<1.0$ & $9.0 \times 10$ & $3.1 \times 10^{3}$ \\
\hline & 計算值 & $1.6 \times 10$ & 6.2 & $9.0 \times 10$ & $1.7 \times 10^{2}$ \\
\hline \multirow{2}{*}{ 2-プロパノール } & 実測値 & $<1.0$ & $<1.0$ & $1.8 \times 10^{7}$ & $3.0 \times 10^{7}$ \\
\hline & 計算值 & $3.1 \times 10^{6}$ & $1.2 \times 10^{6}$ & $1.8 \times 10^{7}$ & $3.4 \times 10^{7}$ \\
\hline \multirow{2}{*}{ 酢酸エチル } & 実測値 & $<1.0$ & $4.7 \times 10^{5}$ & $9.4 \times 10^{5}$ & $1.6 \times 10^{6}$ \\
\hline & 計算值 & $1.6 \times 10^{5}$ & $6.5 \times 10^{4}$ & $9.4 \times 10^{5}$ & $1.8 \times 10^{6}$ \\
\hline
\end{tabular}

: 実測值と計算值が類似

関与していることが考えられる，そこで，香気モデル物 質がフィルム中の水の中を拡散し透過していると考え, フィルムの吸水率 (水浸漬時) および香気モデル物質の 水への溶解度から $100 \% \mathrm{RH}$ 条件での香気モデル物質透 過度を推定した。

フィルムの吸水率（水浸漬時）および香気モデル物質 の水への溶解度を表－6 および表－7 に示す.

フィルムの吸水率および香気モデル物質の水への溶解 度から $100 \% \mathrm{RH}$ 条件での香気モデル物質透過度を推定 するために（1）式を用いた。

$100 \% \mathrm{RH}$ 条件での香気モデル物質透過度 $(\mu \mathrm{g} \cdot 10$ $\left.\mu \mathrm{m} / \mathrm{m}^{2} \cdot \operatorname{day} \cdot \mathrm{kPa}\right)$

$=\mathrm{a} \times$ フィルムの吸水率 $(\%) \times$ 香気モデル物質の水 への溶解度 $(\mathrm{g} / 100 \mathrm{~g})$

[aは定数 $\left.\left(10000 \mu \mathrm{g} \cdot 10 \mu \mathrm{m} / \mathrm{m}^{2} \cdot \mathrm{day} \cdot \mathrm{kPa}\right)\right]$ a の值を $100 \%$ RH 条件における NyMXD6 の酢酸エ チル透過度から求めると, $\mathrm{a}=18615(10000 \mu \mathrm{g} \cdot 10 \mu \mathrm{m} /$ $\left.\mathrm{m}^{2} \cdot \mathrm{day} \cdot \mathrm{kPa}\right)$ であった. そこで, $\mathrm{a}=18615$ を用いて, 他のフィルムおよび香気モデル物質の透過度を求めたと ころ, 表一8の結果が得られた.

表-8より, 吸水率の大きい NyMXD6 および EVOH において実測值と計算值がほぼ一致した。このことか ら，これらはフィルム中に「水の橋」(6) が形成され, 香気 モデル物質がこの橋を拡散していく ‘水中の拡散” が起 こっていることが示唆された. EVOHのシクロヘキサ ン透過度の実測值が計算值よりも大きいのは, EVOH 中のエチレン基とシクロヘキサンの高い相溶性が影響し ていると考えられる.PGA および PET は実測值と計算 值がほとんど一致しなかった。この要因として, PGA お よび PET は吸水率が低く, 水の橋が形成されず水中の 拡散が起こらなかったためと考えられる.

さらに，(1）式を用いて無機ガスである酸素の $30^{\circ} \mathrm{C}$ 
$100 \% \mathrm{RH}$ 条件での透過度を推定してみる。酸素の水への 溶解度は $30^{\circ} \mathrm{C}$ で $0.00359 \mathrm{~g} / 100 \mathrm{~g}$ であるので, NyMXD6 では $3.9 \times 10^{2} \mu \mathrm{g} \cdot 10 \mu \mathrm{m} / \mathrm{m}^{2} \cdot \mathrm{day} \cdot \mathrm{kPa} @ 30^{\circ} \mathrm{C} 100 \% \mathrm{RH}$ となる。 モコン社製 OX-TRAN 2/21 で実際に測定した ところ, NyMXD6 の酸素ガス透過度は $6.9 \times 10^{2} \mu \mathrm{g} \cdot 10$ $\mu \mathrm{m} / \mathrm{m}^{2} \cdot \mathrm{day} \cdot \mathrm{kPa} @ 30^{\circ} \mathrm{C} 100 \% \mathrm{RH}$ であった。この結果 から，無機ガスである酸素でも実測值と計算值はかなり 近い值となり, 無機ガスの透過についても香気モデル物 質と同様に水中の拡散が寄与していると考えられる。

\section{6. 総括}

動的ヘッドスペース法を用いた香気成分透過試験器を 作製し評価を行った結果，これまで官能評価が主であっ た香気バリア性の定量評価に成功した。特に評価が困難 であったバリア性材料の香気成分透過度の測定も可能と なった，香気成分は透過度が極めて低く，セパラブルフ ラスコを用いた静的ヘッドスペース法では再現性の良い 結果を得ることが出来なかった。 そこで, 動的ヘッドス ペース法の香気成分透過試験器を作製し, 蒸気圧の高い 香気モデル物質を用いることにより, 再現性の良い結果 が得られ，バリア性材料の香気成分透過特性を把握する ことができた。特に PGA はPET, NyMXD6, EVOH な どバリア性材料とは違い, 香気成分の構造や相対湿度の 影響を受け難く, 極めて良好な香気バリア性を示した.
キーワード : 香気バリア性，ポリグリコール酸，PGA， 動的ヘッドスペース法

\section{参考文献}

1) 仲川 勤: 高分子フィルムの低分子 (気体, 蒸気) 透過理 論 (3) 一有機蒸気透過理論, 水蒸気透過理論, ピンポール の気体透過など一, 日本包装学会シンポジウム要旨集, 13 , 30-37, (1997).

2) R. Franz: Permeation of Volatile Organic Compounds across Polymer Films. Part I : Development of a Sensitive Test Method Suitable for High-barrier Packaging Films at very low Permeant Vapour Pressures, Packaging Technology and Science, 6, 91-102, (1993).

3 ) R. Franz: Permeation of Flavour Compounds Across Conventional as well as Biodegradable Polymer Films, Foods and Packaging Materials-Chemical Interactions, 45-50, (1995).

4 ) 大須賀弘 : フィルムの香気収着・透過と保香包装, 日本 食品包装研究協会, 72-90, (2006).

5 ）大谷新太郎：モコン社ガスバリア測定装置の測定と信頼 性について，ホーセンテクノ，(2008).

6 ）仲川 勤: 基礎講座 5 包装材料のバリヤ性の科学, 日 本包装学会, 72-74, (2003).

7 ) 松井利郎: 基礎講座 10 包装材料の吸脱着の科学, 日本 包装学会, (2004).

8 ）（株）クラレ：「エバール」樹脂のフレーバーバリア性, (2007).

\title{
Quantitative Study on Aroma Barrier of "Polyglycolic Acid (PGA)" as New High Barrier Material
}

\author{
Kenichi MASUDA, Hiroyuki OBA, Mikio TANAKA
}

KUREHA CORPORATION Polymer Processing Technology Center 18-13, Kamitamari, Omitama-city, Ibaraki-pref 311-3436, Japan

\begin{abstract}
Quantitative evaluation of the aroma barrier of plastic materials was very important for designing the packages of aroma-sensitive contents. The aroma permeability testing was designed with a diffusion cell and dynamic headspace analysis with GC/MS of the lower permeant concentration side of the cell. Cyclohexane, 2-propanol and ethyl acetate with high saturation vapor pressures were used as the permeants analogous to the aroma components such as limonene, 1-butanol and ethyl butyrate respectively. The aroma permeability was measured of the film samples of PGA, PET, NyMXD6 and EVOH. The result showed PGA provided the lowest permeability of all the 3 permeants under both conditions of $0 \% \mathrm{RH}$ and $100 \% \mathrm{RH}$, which fact suggested that PGA is a most suitable barrier material for packaging of aroma-sensitive products.
\end{abstract}

Key words : Aroma barrier, Polyglycolic Acid, PGA, Dynamic headspace analysis 